\title{
'Makhosi a via (Chiefs Commit Ritual Murder)' - Why ritual murders in Southern Africa should be seen as meaningful violence (and not senseless)
}

\author{
Wiebe de Jong
}

Department of Languages and Cultures, African Studies, Ghent University, Belgium

\begin{abstract}
Ritual or muti murder involves the practice wherein parts of the victim's body are removed, usually while the victim is alive, for the purpose of making medicine to politically or economically strengthen those who use it. In this article it is argued that, in order to understand this ritual, we should focus on the cultural dynamics of ritual murder and perceive it as meaningful violence. There is, however, a growing tendency to understand ritual murders in rational, utilitarian terms, which has the inadvertent effect of missing the 'thick description' that may provide insight into the meaning of ritual murders and the question of why it persists in present-day society. As will be explained, with such an approach ritual murders can only appear as senseless. It cuts off the research at the point where it should actually start: with questions of meaning. By presenting historical and ethnographic evidence from South Africa, it is shown that ritual murders were once an accepted means of strengthening the king or chief, and as such, of preserving the whole society. It is argued that in the present day, people still practise ritual murders to politically or economically strengthen themselves, but that this point is neglected in public debate and the media. By focusing on two recent ritual murder cases, it is shown that this neglect has severe consequences for thinking about, and dealing with ritual murders.
\end{abstract}

Key words: ritual murder, violence, medical anthropology, indigenous healing, South Africa

\section{Introduction}

Over the course of time perceptions of what is violent and what is not are subject to change. Even in our own societies we can mention them. While in the Netherlands paedophilia was more or less tolerated in the r97os in certain groups (a bill was even prepared to legalize all kinds of pornography, although it never got enough votes to get through Parliament), today it is heavily condemned in practically every circle of society. The same applies to bull-fighting which, due to heavy protest, has virtually disappeared in the province of Catalonia in Spain. The fact that bull-fighting is still practised in the rest of Spain, shows that perceptions of what is violent are constantly subject to debate. There is, however, a tendency to re-interpret various forms of violence as senseless and irrational. 
The same mechanisms apply to ritual murder in South Africa. Ritual or muti murder involves the practice wherein parts of the victim's body (who is usually still alive) are removed by a group of persons for the purpose of making medicine to politically or economically strengthen those who use it. The underlying idea is that ancestors need to be 'informed' about the sacrifice (Gulbrandsen, 2012). Most victims die either through strangulation while being overpowered by the perpetrators or through severe blood loss after their body parts have been cut off. As told by informants, a hand or tongue can cost as much as $\$ 500$ on the black market. Other scholars have revealed a transnational trade of body parts for medicinal use in Southern Africa (Scheper-Hughes, 2000; Fellows, 2008).

At first glance, the practice does indeed seem gruesome. During four consecutive fieldwork visits to South Africa between 2008 and 2013 all informants I spoke with sharply condemned ritual murders. On a visit to a ritual murder crime scene with a local journalist, for instance, I encountered very angry community members begging to make people 'stop these senseless' practises. In the media, suspects are usually portrayed as either egocentric, superstitious or savage. It is not unusual to find that images of suspects of ritual murder are disseminated in press, even before they have been convicted. Suspects of ritual murder should not expect mercy from their fellow citizens, seems to be the message. Although ritual murders have a relationship with indigenous healing - body parts are mixed with medicine to attain economic or political strength - it is particularly striking to find that indigenous healers and their associations strongly deny in public that body parts have any medicinal use (Muthambi, 2013). The interpretation of ritual murders as senseless and irrational, however, is of relatively recent date. Before African chiefdoms were fully subjected to white administrative and legal authority, ritual murders did - according to its members - make sense.

In this article I will outline that the current discussion in South Africa concerning ritual murders is problematic for a variety of reasons. One of the reasons is that the dominant vision on the use of violence in modern society is seen as a privilege of the state (Elias, 1993). Violence, such as ritual murders, that is being committed outside this framework is seen as deviant, dangerous and something that should be eradicated from society. The result is that little attention is paid to the background and circumstances in which ritual murders occur and what it means for those involved. As such, no sense, no 'thick description' (Geertz, I973), will ever be discovered. They rather, as Blok (2001a: I04) wrote on the difference between meaningful and senseless violence, "close off research precisely where it should start: with questions about the form, meaning and context of violence". With questions like these we can see that, not so long ago, ritual murders and the use of body parts for medicinal use, did make sense and were more or less tolerated by a large part of the population. This might give more insight into the question as to why people in the present day still commit ritual murders. 


\section{Ritual murders as meaningful violence: a theoretical background}

Medicine murder involves the practice wherein parts of the victim's body are removed, usually while the victim is alive, for the purpose of making medicine to politically or economically strengthen those who use it (Murray \& Sanders, 2005). Several scholars have related the existence of medicine murders to the concept of 'life force' (Ngubane, I986; Reis, I997; Tempels, 2006). This concept is based on the idea that in African cosmology, there exists a limited amount of luck in someone's life, also known as life force. The more life force someone has, the more fortunate he will be in strengthening his own position in terms of wealth and prestige (Reis, I997). If someone is successful in life, some people would perceive that this particular person has 'stolen' some life force from someone else (Labuschagne, 2004). One way of obtaining that extra life force is to seek ancestral support through spiritual medicine (Ngubane, I986). Medicine that contains human body parts is considered to be the most powerful, since man follows God and ancestors in the cosmological hierarchy in terms of life force (Tempels, 2006).

To understand the background of ritual murders it is useful to make a distinction between instrumental and expressive aspects of violence (Blok, 200Ia: I07). The former concentrates on the technical aspect of violence: what is the practical reason, the relation between means and goals? The expressive form of violence concentrates on the meaning: which cultural information is transmitted during the violent action? What does it say? In the discussion on ritual murders much emphasis is put on the instrumental aspect. The South African media in particular point to the gruesome natureof killing young people for body parts (Daily News, 20I3). Such sensational journalism intensifies the framing of ritual murder as senseless. Indeed, without a 'thick description' of the murder case, one cannot expect a plausible reason for committing a ritual murder. One should rather investigate in what kind of context the murder took place, which people were involved, what their (common) history might be. Interest in the form, context and meaning of the ritual murder, however, is often understood as offering support to the perpetrator, or, it is understood as an attempt to 'extenuate' the violent act. During my fieldwork, for example, I have had many discussions with people who could not understand why I was conducting research into the meaning of collecting body parts, for it seemed senseless to them. To 'try' to understand, as I continuously stated, is something different than to understand it. The fact that children are often the victim of ritual murder does not make it easier to 'objectively' discuss its meaning.

However, to frame ritual murders as senseless is to close down any space for further investigation. A more fruitful way is to approach violence, including ritual murders, as a "changing form of interaction and communication, a historically developed cultural form of meaningful action" (Blok, 200Ia: I04). The term 'ritual' is instructive here. All rituals have in common that they are repetitive, follow sequences. Leach (I966: 404) has shown that the repetitiveness is to prevent ambiguity in communicating a message. In the execution of ritual murders, for example, it is essential for the perpetrator to collect the body parts whilst the victim is still alive, as its scream will 'alert' the ancestors. The 
'standardization' of the violent act is necessary to be 'understood' by the ancestors, one could say. As such, it is a kind of performance.

To the victim and the community members, a ritual murder might be seen as senseless, uncivilised and beastly. We can trace this line of thought in the idiom that is used to qualify the behaviour of perpetrators of ritual murder. 'Hulle is bobbejane (they are babboons)', I was told by an Afrikaans-speaking South African policeman who had been involved in the investigation of several ritual murder cases. Gulbrandsen (2012: 288) recorded the statement "there's a lion on the loose in the village" after a mutilated teenage girl had been found in Botswana. That is why there is often a violent response from the community. In terms of rational, causational thinking there is no sense in community members in killing an innocent person, since for them the evidence that human body parts can relieve one's personal or medical circumstances is lacking. This is, however, if one solely looks at practical reasons, the instrumental aspect of violence.

If we look at the expressive, symbolic aspects of violence, however, I hope to show below, that to the perpetrator a ritual murder is meaningful. In my view it is exactly this point that we should try to grasp in order to understand the existence and persistence of ritual murders. For researchers it means that, as already mentioned, they should have an intrinsic interest into the form, context and meaning of ritual murders. The body part itself may not contain meaning. It is its biography, its social life (Kopytoff, I986: 66) that creates meaning, that is, the way it has been collected and to whom it belonged. Not the genitals of just any person are cut off for a fertility medicine, but of a child which still carries the potential to blossom.

Consequently, body parts can be seen as agents in the sense argued by actor-network theorists in which they form parts of complexes that co-produce effects in particular situations (Van der Geest, Hardon \& Whyte, 2002: I4). The particular agency of body parts is embedded in the concrete and symbolic associations one can make with it. Such associations can be divided into metaphors and metonyms, into associations that depend on similarity and contiguity. In his much praised, though now accepted as biased book The Golden Bough, Frazer (I922) called metaphoric associations 'homeopathic magic', situations in which like produces like. Although his work has been criticized widely for his Eurocentric views, this way of 'causational reasoning' still applies to various situations. In ritual murders in Southern Africa, for example, eyes are often obtained as 'they can foresee future situations'. Frazer called metonymic associations 'contagious magic', that is, an object that equally affects the person with whom one was once in contact. We see these associations in ritual murders as well. In the days of African kingships, kings would ordain the murder of a young child and bury its bones with the crops. As the boy's bones would grow, the crops would grow simultaneously and the king, as protector of its subordinates, would secure the continuation of the community (De Minnaar, Offringa \& Payze, I992: 2I). In this sense, ritual murders are difficult to comprehend if we do not trace back their symbolic aspects in duties that belonged to the African chieftainship.

Throughout Southern Africa, the existence of ritual murder and the mediating forces of kings and chiefs are known phenomena. Through the written records of early 
anthropologists we know that ritual murders have been committed for at least 150 years, and most likely way before (see for example: Mayr (I907); Lugg (I927); Krige (1936) and Van Warmelo (I977) under entries 'ritual murder' and 'human flesh'). The general idea exposed in these sources is that people live in an environment that is constantly under threat by some kind of misfortune. African medicine was used in these cases to restore and maintain harmony, whether in the body or in the wider society (Murray \& Sanders, 2005: 299). In African thought, ancestral spirits have a vital impact on society and possess the knowledge to heal people. This knowledge is given to indigenous healers like the South African sangoma [plural: isangoma] who are gifted with clairvoyant powers which makes them able to seek contact with ancestral spirits and find the root cause of a particular misfortune. In traditional discourse, it is said that ancestral spirits 'stand' on the shoulder of the sangoma and 'whisper' a remedy to the sangoma [Interview I].

As the ones who stood closely to the ancestral spirits, isangoma in the Zulu chiefdoms in the I8oos were not allowed to practice their sangomahood without permission of the chief (Mayr, I907: 398). The reason was that African chiefs were heavily dependent upon the support of ancestral spirits, for instance, for regular rains to assure a good harvest. Since the chief was seen as the direct descendant of the royal ancestral family, a supra- or non-human force preserving the fertility of the land, it was of vital importance to protect and strengthen him (Turrell, 200I: 24). On the one hand, such action was deemed necessary for the benefit of the whole community, but on the other, it was also also for himself as I will now show.

The idea of a king or chief who carries the responsibility for the well-being of the entire community, corresponds to Frazer's concept of the 'divine king' (Frazer, I922: 293; Graeber, 20II: 2). This concept contains the idea that the health of the king or chief is tied to the fertility and prosperity of the kingdom. If society found out that the king's or chief's powers began to wane, they would (in some cases symbolically) kill him. A weak chief could, after all, could result in starvation or attacks from neighbouring chiefdoms. Since the well-being of the entire community was in the chief's hands, it was important to strengthen him. Ritual murders, consequently, were desired, meaningful and everyone knew that once in a while they had to be committed in order to keep or restore harmony in the community (Ngubane, I986: 203). That clarifies the title of this article which is a traditional saying: 'Makhosi a via (chiefs commit ritual murder)' (Minnaar, Offringa \& Payze, I992: 18).

\section{Methodology}

By presenting historical and contemporary evidence from Southern Africa, I will show that the concept of ritual murders gradually changed. From being a natural fact of life to restore harmony in society, a way of acting meaningfully in African chiefdoms - to being economically and politically attractive for certain people in the present day, though regarded as senseless, uncivilised and irrational by the general population. The data presented in this article are based on historical sources from Southern Africa, archival research, and anthropological fieldwork I conducted during three visits to the field 
between 2008 and 2015 in the South African provinces of KwaZulu Natal and Limpopo.

Archival research took place at the Limpopo High Court in Thohoyandou, the former capital of Venda, an independent state in South Africa from I979 to I994. It experienced a large number of ritual murders during that period. The archives of the Limpopo High Court contain all the criminal records from 1979, the year of Venda's independence, up to the present. The records contain vital information, such as testimonies of witnesses, reconstructions of the crimes, post mortem reports, transcripts of the trials and judgements. In addition, missionary and colonial reports, and monographs of early anthropologists in South Africa have been studied.

Given that ritual murder is often in the news in Limpopo Province, contact was sought with two local newspapers; English-based Limpopo Mirror and Afrikaans-based Zoutpansberger. Both newspapers frequently comment on ritual murders in their vicinity and, as such, during visits in 2013 and 2015, I was able to accompany journalists to ritual murder crime scenes . Interviews were held with suspects, community members and relatives of ritual murder cases, both on the side of the deceased and suspects. In addition, semi-structured interviews were conducted with representatives of the Limpopo High Court who dealt with ritual murder cases and could give insight into classified data. Finally, semi-structured interviews were conducted with an expert on South African and tribal law connected to the University of the North and experts on Venda culture from the University of Venda. Informants were selected on the basis of chain-referral and respondent-driven sampling (Bernard, 2006: I92). This is a method which is frequently used in ethnographic studies that deal with sensitive subjects. The underlying idea is that with this way of sampling one gets transferred by key informants to other informants, who would otherwise be hard to find. Interviews were recorded after approval with the possibility to remain anonymous.

\section{Ritual murders as meaningful violence: historical evidence in Southern Africa during the 2oth century}

As explained above, the existence of ritual murders and the mediating powers of chiefs have always been known phenomena throughout Southern Africa. The practice of ritual murders to strengthen a chief continued well into the first two decades of the twentieth century. Concerning South Africa, the evidence comes, among others, from an account of his Honorary Judge Cecil Jackson who dealt with a court case on a feud between two rival chiefs. Although the account contains a strong ethnocentric bias, it gives a good insight into the context of ritual murders:

"A case in point is that in which Chief Mkandumba (...) and twelve others, were charged with murder. (...) A native woman was openly murdered, the object being, it was alleged, to furnish another Chief, who was not kindly disposed towards Mkandumba, with portions of her body. This placed the latter at disadvantage; human flesh was required, not only to frustrate the machinations of a rival, but also to fructify the corn. The victim must for preference be an alien; and an opportunity presented itself when the Chief, with his retinue, was visiting another section of his 
tribe in a district distinct from his own. An old man, Sitebe, a comparative stranger who had no kinship with the tribe, came to pay his respects. Here, in broad daylight, and in the presence of many people, the Chief gave directions to "watch his buck", followed by the fatal order to take it away. The old man was seized and killed by twisting his head round. The body was conveyed to another kraal, where the required parts were removed by a native doctor, who was accepted as the King's evidence at the trial; and after further dissection was conveyed at night in the Pongola river, into which it was thrown" (Jackson, I9I6: 260-26I).

Apart from this specific ritual murder, Chief Mkandumba was suspected of murdering another man whose fat and hairs were removed (ibid.). Out of this account, which is based on eye witness testimonies heard during court cases, it seems that ritual murders were related to a desire for political strength. Although in most ritual murder cases eye witnesses were usually closely related to the chief, who thus supported him during the trial, evidence was often so strong that many chiefs were sentenced to the death penalty. The account described above shows that Chief Mkandumba ordered his subordinates to kill a person and fetch its body parts in response to the execution of a ritual murder by a neighbouring chief. Body parts were needed to produce a medicine that could protect competing chiefs from eachother.

It is also interesting that Chief Mkandumba ordered his subordinates to kill the person in broad daylight and that, in addition, there were at least twelve accomplices. This supports the idea that ritual murders were accepted as a way to protect one's own society against evil influences, for example from neighbouring chiefdoms.

While ritual murders in South Africa in the first two decades of the twentieth century were mostly instigated by chiefs, Turrell (200I) describes that from the Ig2os the use of human material gradually shifted away from chiefly politics to ambitious commoners. His argument is that due to white intervention in politics, traditional healers escaped the control of chiefs, and sold medicine with human material to people in need of it. Examples range from people who wanted to give a boost to their business to a couple of commoners who want their marriage to be fertile and fruitful.

Ritual murders were, however, not only restricted to South Africa. Interestingly, we see a similar dynamic in other parts of Africa. Below I will present an overview of ritual murders in three of South Africa's neighbouring countries, Lesotho, Swaziland and Botswana to offer some ground for comparison.

In their study on ritual murders in colonial Lesotho, Murray and Sanders (2005) tried to clarify the 'startling' increase that had occurred around the I940s. They found that ritual murders were regularly committed before that time to 'doctor the crops' or strengthen warriors, but that the (perceived) increase was a result of battles between chiefs for more power. During the Ig40s the British pushed through some reforms in terms of (randomly) reducing the number of chiefs. This meant that some chiefs who had gained great respect over the past decades were excluded, while a number of chiefs who had not, were included. As such, several chiefs lost some of their prestige, incomes 
and rights to allocate land (ibid.), which obviously created some dissatisfaction. In addition, there were several quarrels, which lasted years, between chiefs concerning succession after the death of the Paramount Chief in I939. All in all, Murray and Sanders argue that this has led to the feeling that ritual murders were on the increase, because chiefs needed a big 'medicine horn' to enlarge their political powers.

At the end of their book, Murray and Sanders provide examples of other cases, among others Swaziland, which provide indications that ritual murders were on the increase. Although ritual murders were a known fact in colonial Swaziland, its number seemed to increase after the country's independence in I966 (Kuper, I986).

"There had been mysterious accidents, and strange rumours heightened by a disturbing increase in murders practiced by people, some in responsible positions, who believed that by using human flesh, they could get more respect and influence for themselves. (...) There was a pathological increase in theft, in disputes over property, in family conflicts, and threaths of industrial unrest" (Kuper, I978 in Murray and Sanders, 2005).

In a later study, Evans (I993) concentrated on court records between I970 and I988 and found that more than half of all the cases ( 58 cases in total) occurred between 1970 and 1975, in the aftermath of Swaziland's independence. In quite a lot of cases, chiefs were the instigators who were looking for a powerful medicine to gain more political power. Interestingly, Evans pointed out that in 30 percent of the cases studied, the main cause for a ritual murder was not political power, but economic profit to buy luxury goods such as a car or to boost one's business. Van Fossen (1985: 3 in Evans, 1993), writing on the same subject about a decade earlier, endorsed this standpoint and argued that medicine murders were committed by 'petty chiefs and headman who together form the 'petty aristocracy'. They were "threatened with loss of autonomy, and hence loss of authority, as a consequence of the King's consolidation of power after independence" (ibid.).

In the same vein, Gulbrandsen (2012: 283) comments on the discourse on ritual murders in Botswana in which the instigators are identified as abusers of power and occult practitioners. He argues that up to the middle of the twentieth century chiefs were the only ones who were allowed to instigate a ritual murder in order to produce a muti for agricultural purposes or to protect the community against enemies; that is, for the well-being of the entire community as earlier mentioned. However, with the urbanization and the construction of a bureaucratic state after Botswana's independence in I966, the importance of chiefs and their duties decreased. As a result of a growing industry, a new middle-class developed that benefited from the increasing state resources. Yet, the majority of the population did not profit and remained poor, which caused the rumours that the nouveau riches used certain muti that made them wealthy. With the loss of the chief as head (and benefactor) of the entire community, there was a "sense that magical potencies [had] to some extent broken free from their control and integration within hierarchical social orders" (Gulbrandsen: 292). The mere fact that more and more traditional healers 
migrate as relatively strangers to urban centers and serve only their personal interests, stands in opposition to the idealized harmonious village life that was ruled by the chief. Although Gulbrandsen does not provide us with exact figures of an increase in ritual murder, there is a general feeling that it is on the rise.

What these cases have in common is that in times of dramatic change there seems to be an increase in ritual murders that goes together with political and economic tensions. But were ritual murders as common and as much a 'fact of life' as described by igth and early 2oth century ethnologists? Did they really occur or were they rather part of Western, ethnocentric imagination, an attempt to designate African culture as 'savage'?

In the case of Lesotho, Murray and Sanders pointed out that chiefs condemned the British colonizer for accusing them of being the instigators of ritual murder. The chiefs argued they were incriminated to exclude them from political positions so the colonizers could make it easier to transfer Lesotho to South Africa (Murray \& Sanders, 2005: 4). The defensive attitude of the chiefs was not that surprising, since previous court cases revealed they were the main suspects of ritual murders. In 1949, for instance, two of the highest chiefs were hanged after they had been convicted of ritual murder. The reason was that they had been given orders to ambush one of their subordinates and cut off his lips to strengthen their 'medicine horn', that is, their personal strength. Conspiracy thinkers in Lesotho argued that there was no such thing as 'medicine murder', but that it was rather a white invention. It seems, however, that within society, because of widespread publicity on the murder cases, it gave rise to revulsion and contempt towards the chiefs (Murray \& Sanders: 284). Not everyone accepted ritual murders as a way to restore harmony anymore.

Interestingly, the authors Murray \& Sanders reject the idea that ritual was a fiction invented by the British colonizers to suppress the chiefs. Through court reports, newspapers and (still alive) eye witnesses, they found 2 Io cases of alleged ritual murders between I895 and I966 (Murray \& Sanders, 2005: pp. 350 ff) Almost all of them were instigated by chiefs. The authors relate the increase of ritual murders to a moral crisis: ritual murder as a way to deal with political insecurity and economic hardship.

The explosive increase of ritual murders in the Ig8os in the newly raised independent Republic of Venda seems to be an example of this phenomenon. In I979 the Venda homeland in the northeast of South Africa became independent from South Africa. Not long after its independence, Venda was confronted with a spate of ritual murders. There was a feeling in society, intensified by rumour and media reports, that chiefs were behind the events. In fact, the proliferation of ritual murders in the Republic of Venda was a complex result of political corruption and the perversity of apartheid (Ritchken \& Koch, I99I). In I95I, the South African apartheid government created Black Homelands which were supposedly created to allow the black population govern themselves and to preserve their culture. In reality, however, it was in line with the government's policy of 'divide and rule' (Bangstad, Eriksen, Comaroff, \& Comaroff, 2012).

Mihálik and Cassim (1993) argue that for decades the Black Homelands were relatively peaceful, largely because of the partial respect and legitimacy accorded to tradition- 
al political authority, such as chiefs. Prior to the creation of the Homelands, the functions of the chieftainship included, among others, judicial powers, executive powers in the allocation of land and a number of ritual and spiritual functions. Substantive political power was in the hands of the institution called Koro, the chief's council of elders. Ritchken and Koch (I99I) state that with the implementation of the Black Authorities Act in I95I, which created the legal basis for the Homelands, chiefs in effect became civil servants. As such, they were accountable to a commissioner appointed by the racist Nationalist Government. Chiefs no longer represented the interests of their community, but that of the state. When Venda became independent in I979, it was given a constitution which set up a legislative assembly with a majority of government-nominated chiefs over elected members. The chiefs were now accountable to the Venda Parliament, effectively part of the apartheid system, and were chosen by the black dictatorial regime of the 'President for Life', by then president Mphehphu (Mihálik \& Cassim, 1993). This resulted in a great deal of anxiety amongst the chiefs about their position.

Ritchken and Koch further showed that to preserve their position, chiefs appointed all government ministers and senior officials from their own ranks. This development resulted in a political vacuum and widespread corruption. But it also had decisive consequences for ritual murders. In order to accumulate wealth and political power, chiefs and their allies committed ritual murders to strengthen themselves - just as chiefs had done in traditional times. It also resulted in allegations that people arrested in connection with medicine murder were released by order from above (Le Roux, I989). Moreover, chiefs accused each other of medicine murder to protect their own political position. As such, African chiefs in search of political power in the new state and historically associated with ritual murders were mainly held responsible by public opinion and authorities. After apartheid this even led to the establishment of two independent commissions to account for the increase of 'witchcraft-related' crime in the I980s in Venda. Even today the region is known for the frequent execution of ritual murders.

\section{Examples of ritual murders in Venda}

The relatively high incidence of alleged ritual murders led me to conduct fieldwork in the Venda region in the Limpopo province in South Africa. With access to journalists of local newspapers who had reported on several ritual murder cases, police officials, court magistrates, and relatives of victims and perpetrators I was able to gain much information on past and present ritual murder cases. Although ritual murders seem to occur more often in Venda than elsewhere in South Africa, the alleged rate used to be higher in the I980s (Interview 2). Yet, from January to October 2013 the newspapers Limpopo Mirror and the Zoutpansberger reported at least 6 alleged ritual murders. Although all bodies share in common that when they were found with body parts missing, it is still to be confirmed that the events do concern ritual murder, as some court cases are still pending.

As described above, chiefs in the last two decades of the twentieth century were depicted as the main instigators, although such claims were not always justified. Due to the attention given to ritual murders, society was confronted with the power of rumours, 
spread by media reports and gossip. Sometimes, and even today as I will show later, this led to inaccurate descriptions. In some cases people were falsely accused, while other recent cases have unjustly been defined as ritual murder.

From I979 to I988 (when Venda was an independent state), I6 ritual murders were reported in official records, rising to 39 between January and August I988 following the death of the state president (De Minnaar, Offringa \& Payze, I992: 22). What was the background of this high rate of ritual murders? Testimonies by eye witnesses and accomplices reveal that either political or economic motives were behind the quest for body parts. According to Mathagu, (I990: I8) after Venda's independence in I979 "development planning was geared to the transformation of Venda from a traditional to a modern state and Developmental Corporations were established to assist in that process". Many unqualified state officials and ministers received high-ranking jobs through bribery and nepotism, and they in turn provided loans to their patrons, many of whom started their own business, though they lacked any education or experience. As such, businessmen allegedly sought ways to accumulate large profits by means of powerful medicine. Below are two accounts of ritual murder that were tried in court and took place during Venda's independence. In both accounts we can see that the instigators saw their deed as meaningful - though ruthless - in terms of collecting body parts to empower their political or economic strength.

Around 30 June I988 a 2-year old child went missing Although the body was never found, accomplices confessed that they belonged to a group of nine people that conspired to kill the child. Amongst them were the grandparents, a traditional healer, a butcher, two local businessmen, the Director-General of Intelligence of Venda and others (State vs. Bethuel Mathabi and seven others (CCI/89)). It was alleged that the two businessmen were about to open a motel business. In order for the business to thrive they wanted a medicine that was made with human flesh. Contact was sought with the grandparents of the 2-year old child who were promised a large amount of money. The grandparents requested the assistance of a 22-year old man who often took care of the child and brought the child into the nearby hills.

When they arrived, the child was handed over to the butcher who hit the boy's head against a brick. Whilst the child fell in a state of unconsciousness, the butcher cut off the lips, half the tongue and subsequently its head. The grandfather thereafter removed the child's penis. All body parts were taken by one of the businessmen who allegedly buried them at specific places in the motel, although never found. Both the grandfather of the deceased, the butcher who actually killed it and one of the businessmen all received the death sentence. The other businessman, however, who many framed as the mastermind behind the murder was acquitted due to lack of evidence since he did not attend the murder. Most of those involved were poor and unemployed, and participated because of the large sum of money that they were promised.

We can see an interesting parallel here with the social circumstances concerning ritual murder in Botswana previously dealt with that might give answer to the question why people get involved with ritual murder. Gulbrandsen (2003: 226) notes that: 
"The specific exigencies of urban living - problems with finding employment, navigating the local bureaucracy, gaining access to educational opportunities, acquiring property and establishing local security - result in these aspects of urban life being realised as negative qualities that demand the magical intervention of dingaka [traditional healers]".

A second account that was also tried in Venda Court deals with an instigator who was seeking more political power - It concerns Chief Ramovha who was of royal descent and chief of his community. He was found guilty of medicine murder in 1982 . Before the independence of Venda in 1979 he occupied a high position in government as Deputy Minister of Post and Telegraphs (Truth \& Reconcillation Commission, I999), but found himself unable to attain that position in the newly erected state:

"During the court case it was neglected that Chief Ramovha had failed to be chosen in the cabinet of the Republic of Venda in I98I by the State President. To promote his own image he needed human body parts to strengthen himself" [Interview 2].

As was revealed by the accomplices, Chief Ramovha had ordered three of his subordinates to approach a local teacher after they had been drinking in a bar. In a failed attempt to overpower him with an iron object, the teacher was fatally hit by a gun shot. Subsequently, he was transported to a nearby river where his arm, eyes, tongue, lip and genitals were cut off (State vs. Ramovha and I other, I982: 6-II):

"In addition, Chief Ramovha took some of his leg bones, ribs, liver, kidneys, liver and heart. The kidneys, liver and heart were eaten by Chief Ramovha. The liver and kidneys contain the function to detox the body, and the heart was used to strengthen his own heart. The ribs were buried just in front of his doorstep. The ribs protect the heart. The rest of the body parts were burnt and buried with his crops." [Interview 2].

Eventually, Chief Ramovha and his accomplices were taken into custody. Although his accomplices had physically killed the teacher, Chief Ramovha was the only one who received the death penalty as the judge found him guilty of being the main instigator. Though 'belief in sorcery' was sometimes applied as an extenuating circumstance, in this case it was argued that Chief Ramovha "should have known better, as he used to be deputy minister in the cabinet". It is remarkable to notice that during the trial no questions were raised about the reason for committing the ritual murder. As if it was not appropriate to look for the 'meaning' - in this case the fact that Chief Ramovha needed a strong medicine to safeguard his high position in the cabinet.

The avoidance of looking for the meaning of violence is characteristic of a society where the vision that violence is a privilege of the state is becoming more dominant (Elias, 1993). An inadvertent effect, however, is that all violence that does not fit within 
that scope, is seen as senseless and irrational. It is therefore no wonder that in the late I980s and the beginning of the I99os rumours of ritual murders, supposedly committed by prominent figures, led to heavy protests and mass demonstrations in the Republic of Venda [Interview 2].

What happened here was that most attention went to the instrumental aspects of ritual murders. As described earlier, those are the aspects that concentrate on the questions that are involved with the relation between means and goals. In a society where violence is monopolized by the state, all other violence, consequently, is depicted as senseless.

Such an approach does not allow room for raising further questions about the expressive forms of ritual murders. Those are the aspects that deal with questions of form and context, as I have shown above. For example, which cultural information is transmitted during ritual murders? What does it say? It seems that, due to the emphasis on the instrumental aspects of ritual murders, people have forgotten that ritual murders used to be, and for some still are, meaningful, a way for an individuals to strengthen themselves, as the king or chief used to do. However, to admit that ritual murders make 'sense', may be interpreted by some as an attempt to extenuate the crime. In contrast to ritual murder cases in the nineteenth and early twentieth century, people have become more inclined to consider these cases as senseless, irrational and barbaric. Up to the point where important cultural information gets overshadowed and all meaning is lost.

I will now show that the current debate on ritual murders in South Africa suffers from this handicap. Consider the two fragments of alleged ritual murder cases below that took place in Venda in 2012 and 2013 and that were highlighted while I was there conducting fieldwork.

\section{'The Hand Case'}

Rumbidzai Mayere was a 34-year old Zimbabwean female who only lived for a few months in South African border town Makhado (Louis Trichardt) to find a better life, when she was reported missing. About three weeks after she moved there, the neighbourhood was shocked when 38-year old Freddy Tshikudo stormed into a shop owned by Indians, holding a human arm in his hands. Allegedly, Tshikudo had been promised 70,000 Rand and a motor vehicle by the Indian owners for supplying them with a human arm to produce a strong muti. Because of all the commotion, the police could quickly arrest Tshikudo who had to explain to whom the arm belonged. Soon after, he confessed and took the police to a nearby bush where the corpse of Rumbidzai Mayere was found. Apart from her arm, both her eyes and private parts had been removed. The latter parts have never been found.

During the same week, a local newspaper covered the story and placed several photos and videos on its website, describing it as a 'gruesome muti murder', quite soon referred to as 'The Hand Case' (Venter, 2013). According to the journalist on duty, the missing body parts proved beyond reasonable doubt that it was a ritual murder. The case caused great anger within the local Zimbabwean community who showed their utter disgust during the court case by displaying slogans that said 'Stop killing us like dogs'. Ac- 
cording to Zimbabwean community members I spoke with, the murder was senseless for human body parts would not cure any disease. Freddy Tshikudo was sentenced to life imprisonment, but maintains that he was falsely incriminated by the Indian shop owners. They would have stored the human arm in their freezer and made people believe that Tshikudo committed the murder [Interview 3].

'The Sangoma Case'

A year before, 52-year old Philip Bendzani was allegedly ambushed by six men when walking out of a local township bar. Soon after, the group removed the victim's pubic hair and testicles and subsequently set him alight. The case was rapidly referred to as 'The Sangoma Case', since the main instigator, and neighbour of the victim, was a traditional healer (Muthambi, 20I2). Local community members saw a relationship between the body parts for producing human medicine and the arrested traditional healer. A few days after the incident, angry community members were looking for revenge and set light to the sangoma's house. They also set his goats alight and removed their eyes while alive, while the sangoma's two wives and sixteen children had to run for their lives.

\section{Discussion}

Through interviews with the public prosecutor [Interview 4], journalists [Interview 5] and community members [Interview 6 ; 7] I found out that they were quite convinced that both cases were typical ritual murders. As in the independent Republic of Venda in the late I980s, the proclamation that it concerned ritual murders provoked severe indignation and in some cases a violent response. The chairman of the Traditional Healers Association pointed, in particular, to the irrationality of the murder in 'The Hand Case': “... Killing people for muti purposes is uncalled for [because] (...) parts removed from human beings cannot make muti" (Venter, 2013).

The public arena was quick in their claim that both 'The Hand Case' and 'The Sangoma Case' were ritual murders. But were they? Further investigation into both cases made me doubt. After I had been showed the photographs of the corpse in 'The Hand Case' by the police, I was first of all pointed to the white veins on the arm of the corpse by the captain of the police department [Interview 8]. If they had been red it would indicated that the arm had been cut off while the victim was still alive, which is normally the case with ritual murder cases. In the introduction to this article I described how the ritual murders are carried out while the victim is still alive, since the scream of the victim 'informs' the ancestors. The convicted murderer, Freddy Tshikudo, however, stated that he off the arm a week after the deceased death (State vs. Tshikudo (CC 73/2013)) - Tshikudo however withdrew his confession in court, claiming he had been been forced with violence by the police to make him confess, though DNA had been found.

Secondly, Tshikudo allegedly acted on his own, while usually ritual murders are planned way ahead by a group of people. The archives of the Thohoyandou High Court contain quite a lot of court cases in which a group of usually three to four men ambush a chosen person and strip him from particular body parts. Usually, one of them is the 
instigator who wants to improve his position with medicine made of human material and carefully selects people around him to seize the victim. Tshikudo never sought the help of others, let alone a traditional healer to produce a muti (De Jong, 20I5).

'The Sangoma Case' also cast some doubts on the question of whether this was indeed a ritual murder. In interviews with community members I was told that the victim had a secret love affair with one of the wives of the main suspect, his neighbour [Interview 9]. As such, it might be possible that the motive was not ritual murder, but one of revenge. On his studies of adultery in the Mediterranean, Blok explains that the dishonour felt by the deceived husband can be so fierce that the only way to 'remove and cleanse its stains is by shedding blood' (Blok, 200Ib: 203). By cutting off the penis, as happened in 'The 'Sangoma Case', ultimate vindication is found, through a literal amputation of the victim's manhood, and thus his honour (Pitt-Rivers, I966: 29). In both ritual murder cases described above, rather than focusing on the symbolic and contextual (expressive) aspects of the murders, emphasis was put on the technical (instrumental) aspects; that is, the conclusion that both cases were ritual murders because body parts were missing.

\section{Conclusion}

What I have been trying to say in this article is that meaning can be found by concentrating on the expressive aspects of violence. Violence is often moulded into a kind of performance which we need to unravel. When studying the practice of ritual murders, we should not only pay attention to the fact that body parts are missing, but should also look for connections between those involved, their cosmologies, power relations and contextual aspects. I propose focussing on the 'ritualization' of ritual murders. In 'ritual' we find the attempt to cast out anomalies, a focus on formalization and structure, in which the happenings are presented as a performance. By bearing that in mind, we can distinguish ritual murders from different kinds of murders, with their own particularity and contextual aspects. It also provides insight into symbolic acts which are traceable in historic sources when ritual murders were meaningful to individuals and society.

One serious problem, however, is the lack of evidence usually collected in ritual murder cases. First of all, dismembered corpses are often not found, let alone their body parts. Due to large (professional) trade networks with many people involved it becomes harder to trace the receiver. Secondly, instigators who are willing to pay a lot of money for certain body parts usually do not attend the actual killing of the victim, but hire the services of at least one traditional healer and people who are in need of money. As a consequence, the instigator does not get arrested. Finally, once in court, suspects often do not open up about their or their patron's motives.

A more thorough 'thick description' could be achieved by circumventing official sources and look for meaning among some surviving (relatives of) victims, accomplices, convicts and other observers. Their recollections should give more insight into how to interpret the particular context, the alleged motives, circumstances and social complexities of ritual murders which have not been recorded in court - or have never reached court. It is also likely to provide insight into the relationship between victims and perpetrators, 
and the aftermath of the events. The proposed methods will be applied in a follow-up study of this project and will hopefully shed more light on the sense of ritual murder in contemporary Southern Africa.

Because ritual murders always make sense from at least one point of view - the view of the instigator(s) - and "given the anthropologist's interest and expertise in culture and the minutiae of social life", as Blok (200I: 9) notes, "he has a special license to explore these meanings and their anchoring in social life". It is only with such an approach, as I have demonstrated, that we can overcome the risk of proclaiming ritual violence as senseless, and as a consequence, run the risk of overlooking important features.

\section{References}

Bangstad, S., Eriksen, T.H., Comaroff, J.L, \& Comaroff, J. (2012). 'Anthropologists are Talking': About Anthropology and Post-Apartheid South Africa. Ethnos: Journal of Anthropology, Vol. 77(I), pp. II5-136.

Bernard, R. (2006). Research Methods in Anthropology. Oxford: AltaMira Press.

Blok, A. (2001a). The Meaning of 'Senseless Violence' In: Blok, A. (eds.) Honour and Violence. (pp. 103II4). Malden: Blackwell Publishers.

Blok, A. (20orb). Mediterranean Totemism: Rams and Billy-Goats. In: Blok, A. (eds.) Honour and Violence. (pp. 173-209). Malden: Blackwell Publishers.

Daily News (2013). Albinos Seek Monarch's Protection.

De Jong, W. (2015). "Hand Case not a typical Ritual Murder Case". Limpopo Mirror, July r6.

De Minnaar, V., Offringa, D., \& Payze, C. (1992). To Live in Fear. Witchburning and Medicine Murder in Venda. Pretoria: Human Sciences Research Council.

Elias, N. (1993). The Civilizing Process: Sociogenetic and Psychogenetic Investigations. Oxford: Blackwell.

Evans, J. (1993). 'Where can we get a Beast without Hair?' Medicine Murder in Swaziland from 1970 to 1988. African Studies, Vol. 52(I) 27-42.

Fellows, S. (2008). Trafficking Body Parts in Mozambique and South Africa. Maputo: Human Rights League.

Frazer, J. (1922). The Golden Bough. A Study in Magic and Religion. London: Macmillan.

Geert, C. (1973). The Interpretation of Cultures. New York: Basic Books.

Graeber, D. (20II). The Divine Kingship of the Shilluk. On Violence, Utupia, and the Human Condition, or Elements for an Archeology of Sovereignty. HAU: Journal of Ethnographic Theory, Vol. I(I) I-29.

Gulbrandsen, Ф. (2003). 'The Discourse of Ritual Murder'. Popular Reaction to Political Leaders in Botswana. In: Kapferer, B. (eds). Beyond Rationalism, Rethinking Magic, Witchcraft and Sorcery. New York: Berghahn Books (215-233)

(2012). The State and the Social: State Formation in Botswana and its Pre-colonial and Colonial Genealogies. New York: Berghahn Books.

Jackson, C. (Igr6). Native Superstition in its Relation to Crime. Report of the South African Association for the Advancement of Science. Vol. I3 25I-263.

Kopytoff, I. (1986). The Cultural Biography of Things: Commoditization as Process. In: Appadurai, A. (eds.) The Social Life of Things: Commodities in Cultural Perspective. (pp. 64-94). Cambridge: Cambridge University Press.

Krige, E. (1936). The Social System of the Zulus. Pietermaritzburg: Shuter and Shooter.

Kuper, H. (1978). Sobhuza II: Ngwenyama and King of Swaziland. The Story of an Heriditary Ruler and his Country. New York: Africana Publishing Company. (1986). The Swazi: a South African Kingdom. New York: Holt, Rinehart and Winston. 
Labuschagne, G. (20I2). Muti Murder: Murder for Human Body Parts. In Borgson, K, \& Kuehnle, K. (eds). Serial Offenders. Theory and Practice. Sudbury: Jones \& Bartlett Learning (I45-I62).

Leach, E. (1966). Ritualization in Man in Relation to Conceptual and Social Development. Philosophical Transactions of the Royal Society of London, Vol. 25I, 403-408.

Le Roux, D. (1989). Report of the Commission of Inquiry into the Causes of the Unrest and Ritual Murders in Venda During 1988. [Unpublished].

Lugg, H. (1927). Agricultural Ceremonies in Natal and Zululand. Bantu Studies, Vol. 3(I) 357-383.

Mayr, Fr. (1907). The Zulu Kaffirs of Natal. Anthropos, Vol. 2(3) 392-399.

McCord, J. (1926). Native Witch Doctors and Healers. South African Medical Record, Vol. 24, pp. 195-205.

Mihálik, J., \& Cassim, Y. (I993). Ritual Murder and Witchcraft: a Political Weapon? South African Law Journal, Vol. IIo, pp. I27-I40.

Murray, C., \& Sanders, P. (2005). Medicine Murder in Lesotho. The Anatomy of a Moral Crisis. Edinburgh: Edinburgh University Press.

Muthambi, P. (2012). Turmoil at Ha-Mutonga. Zoutpansberger, June I, 2012. (2012). Ritual Murder? Limpopo Mirror, May 30, 2012.

Ngubane, H. (1986). The Predicament of the Sinister Healer. In: Last, M., \& Chavunduka, G. (eds.). The Professionalization of African Medicine. (pp. I89-204) Manchester: Manchester University Press.

Pitt-Rivers, J. (I966). Honour and Social Status. In: Peristiany, J. (eds). Honour and Shame: the Values of Mediterranean Society. Chicago: Chicago University Press.

Reis, R. (1997). Menselijk Material als Medicijn. Over Rituele Moord in Swaziland. [Human Material as Medicine. On Ritual Murder in Swaziland] Medische Antropologie, Vol. 9(2), pp. 362-376.

Ritchken, E., \& Koch, E. (I99I). 'A Chief is Always a Witch'. The Politics of Witchcraft. Cross Times, February/March, pp. 49-5I.

Scheper-Hughes, N. (2000). The Global Traffic in Human Organs. Current Anthropology, Vol. 4I(2), pp. I9I-224.

Tempels, P. (2006). [1959]. Bantu Philosophy. Paris: Présence Africaine.

Turrell, R. (200I). Muti Ritual Murder in Natal: From Chiefs to Commoners (Ig00-I930). South African Historical Journal, Vol. 44, pp. 2I-39.

Van Fossen, A. (1985). Ritual Murder, Polity and Identity in Swaziland. Paper presented at the 8oth Congress of the International Association for the History of Religions, Sydney.

Van Warmelo, N. (eds.). (I977). Anthropology of Southern Africa in Periodicals to 1950. Johannesburg: Witwatersrand University Press.

Venter, I. (2013). Muti Murder Shock, Case takes Dramatic Turn. Limpopo Mirror, April I2, 2013.

\section{Interviews}

Interview 1

Interviews with Mathabo Hlahlane, sangoma and medical practitioner at Sasolburg Hospital, South Africa. Interviews were carried out on several occasions in 2008 and 2013.

\section{Interview 2}

Interview with the magistrate of the regional court in Makhado (Louis Trichardt) who used to be the legal advisor and interpreter of Chief Ramovha during his trial and attended several ritual murder court cases. The interviews took place at July 28 and August 6, 2013.

Interview 3

Interview held with Freddy Tshikudo, convicted of ritual murder and trade in human tissue on July 2, 2015. The interview took place on July ig at Matashe prison, Thohoyandou. 


\section{Interview 4}

Separate interviews with two public prosecutors of Makhado Regional Court who dealt with 'The Hand Case'. The interviews took place in the Regional High Court in Makhado (Louis Trichardt) on July 28 and August 2, 2013.

Interview 5

Separate interviews with two journalists working for the local newspapers Limpopo Mirror and Zoutpansberger who dealt with 'The Hand Case' and 'The Sangoma Case'. The interviews took place on a daily basis in July-August 2013.

Interview 6

Group interview with Zimbabwean community members and the sister of the deceased in 'The Hand Case'. The interview took place in Makhado on July 26, 2013.

Interview 7

Interview with the traditional leader, khosi, of the community in which 'The Sangoma Case' took place. The interview took place in Elim on August 7, 2013.

Interview 8

Interview with the captain of the police department in Makhado (Louis Trichardt) who dealt with 'The Hand Case'. The interview took place at Makhado Regional Court on August 2, 2013.

Interview 9

Interview with community members, living in close proximity to the families of the deceased and the main suspect. The interview took place in Elim on August 3, 2013.

\section{Judicial information written in court cases}

State vs. F. Ramovha and one other (1982: no. of case unknown).

State vs. Bethuel Mathabi and seven others (CCr/rg89)

State vs. Freddy Tshikudo (CC73/2013) 